\title{
Anthocyanins and anthocyanin-degrading enzymes in Kwai May and Wai Chee cultivars of litchis grown in Reunion Island and Spain
}

\author{
Marie-Noëlle Ducamp-Collin*, Marc Lebrun, Hassina Ramarson, Guy Self
}

Cirad-Persyst, UMR Qualisud, TA B-95 / 16, 73, rue JeanFrançois Breton, 34398 Montpellier Cedex 5, France marie.noelle.ducampcollin@cirad.fr
* Correspondence and reprints

Fruits, 2007, vol. 62, p. 353-359 (C) 2007 Cirad/EDP Sciences All rights reserved DOI: $10.1051 /$ fruits:2007033 www.fruits-journal.org

RESUMEN ESPAÑOL, p. 359
Anthocyanins and anthocyanin-degrading enzymes in Kwai May and Wai Chee cultivars of litchis grown in Reunion Island and Spain.

Abstract - Introduction. After harvest, litchi fruits (Litchi chinensis Sonn.) rapidly lose their bright red skin color. Peel browning of harvested litchi fruit has largely been attributed to rapid degradation of red anthocyanin pigments associated with the oxidation of phenolic compounds by polyphenol oxidase (PPO) and/or peroxidase (POD). An anthocyanase has been also identified in litchi peel. Our work aimed at characterizing two specific litchi varieties that differ greatly in their color and browning behavior. Materials and methods. The anthocyanins, polyphenol oxidase (PPO), peroxidase (POD) and anthocyanase in the pericarp of two litchi cultivars, Kwai May and Wai Chee, grown in Reunion Island and Spain, respectively, were studied. Results and discussion. The qualitative composition of major anthocyanins (cyanidin-3-rutinoside and cyanidin-3-glucoside) was identical for the two cultivars studied, but, quantitatively, the variety Kwai May had a lower concentration than Wai Chee (64\% less) of cyanidin-3-rutinoside. This component represented more than $90 \%$ of total anthocyanins in both cultivars. The activity of PPO was 6 times greater in the variety Kwai May than in Wai Chee and the activity of POD 30 times greater. The activity of POD was greater than that of PPO in both varieties. These differences help to explain the different behaviors of the cultivars during subsequent postharvest studies.

Reunion / Spain / Litchi chinensis / fruits / pericarp / color / anthocyanins / catechol oxidase / peroxidases / phenolic content

\section{Anthocyanines et enzymes de dégradation des anthocyanines dans le péricarpe des cultivars de litchi Kwai May et Wai Chee cultivés à l'île de la Réunion et en Espagne.}

Résumé - Introduction. Après récolte, les fruits du litchi (Litchi chinensis Sonn.) perdent rapidement la couleur rouge lumineuse de leur peau. Le brunissement du litchi récolté a été en grande partie attribué à la dégradation rapide, dans la peau, des colorants rouges d'anthocyanine liés à l'oxydation des composés phénoliques par l'oxydase de polyphénol (PPO) et/ou la peroxydase (POD). Une anthocyanase a été également identifiée dans le péricarpe du litchi. Nos travaux ont cherché à caractériser deux variétés spécifiques de litchi différant considérablement quant à leur couleur et à leur brunissement. Matériel et méthodes. Les teneurs en anthocyanes, oxydase (PPO) de polyphénol, peroxydase (POD) et anthocyanase du péricarpe de deux cultivars de litchi, Kwai May et Wai Chee, développés respectivement à l'île de la Réunion et en Espagne ont été étudiées. Résultats et discussion. La composition qualitative des anthocyanines prépondérantes (3-rutinoside de cyanidol et 3-glucoside de cyanidol) a été identique pour les deux cultivars étudiés, mais, quantitativement, la variété Kwai May a eu une concentration en 3-rutinoside de cyanidol inférieure à celle Wai Chee ( $64 \%$ en moins). Pour les deux cultivars, ce composant a représenté plus de $90 \%$ des anthocyanines totales. L'activité de la PPO a été 6 fois plus grande pour la variété Kwai May que pour Way Chee et l'activité de la POD a été 30 fois plus grande. L'activité de la POD a été plus grande que celle de la PPO pour les deux variétés. Ces différences aident à expliquer les différents comportements des cultivars pendant les études après récoltes.

Réunion / Espagne / Litchi chinensis / fruits / péricarpe / couleur / anthocyane / catéchol oxydase / péroxydase / teneur en phénols 


\section{Introduction}

Of Asian origin, the litchi (Litchi chinensis Sonn.) is prone to a number of postharvest problems, among which the most important is browning of the pericarp. This phenomenon occurs less than $72 \mathrm{~h}$ after harvest [1$3]$. Although the organoleptic quality of the aril is not changed, the fruit loses commercial value due to the loss of the vibrant red color.

The red coloration of the litchi is due to the presence of anthocyanin pigments [4-5]. Cyanidin-3-rutinoside and cyanidin-3-glucoside have been identified as the major anthocyanins present in the litchi pericarp [5-8]. The intensity of the coloration of the anthocyanins depends on $\mathrm{pH}$, which influences their structure. The flavylium form is stable at acid $\mathrm{pH}$ and is colored red, but, at basic $\mathrm{pH}$, it is transformed into its carabinol base (colorless), into chalcone (yellow), or into its quinonic base (blue) [9].

A number of authors have linked browning of the pericarp to a degradation of anthocyanins by the action of polyphenol oxidase [10-14]. Enzymes such as polyphenol oxidase (PPO) and peroxydase (POD) are primarily membrane-bound, whereas anthocyanins are vacuolar ([6]). Contact between the enzyme and substrate cannot therefore take place unless there is disrup-

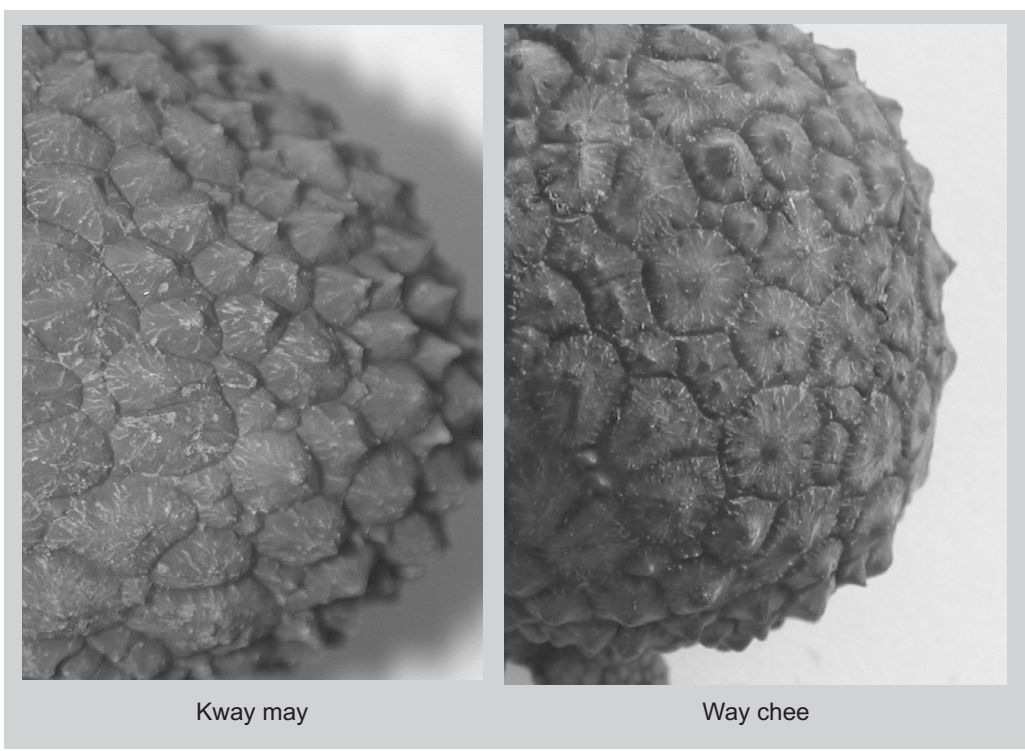

tion at the cellular level. Thus, browning can follow different types of stress, such as climatic conditions preceding maturation of the fruit, disease, desiccation and thermal shock [15].

The principal postharvest treatment currently used for litchi is fumigation with sulfur dioxide $\left(\mathrm{SO}_{2}\right) . \mathrm{SO}_{2}$ is a strong antioxidant that blocks oxidation, causing skin browning. Furthermore, it acidifies the cellular contents of the pericarp, thus stabilizing the anthocyanins. $\mathrm{SO}_{2}$ is also an antifungal agent [16]. Nevertheless, the treatment has limitations. Fruits do not recover their initial red coloration after treatment [17] and, more importantly, sulfur residues can reach the aril, where they represent a health risk for people allergic to sulfur. In the USA, the application of $\mathrm{SO}_{2}$ is banned on all food products, except grapes [3, 18].

Several alternative treatments to $\mathrm{SO}_{2}$ fumigation have been proposed: for example, soaking in a solution of $\mathrm{N}_{6}$-benzyladenine [19], the combined use of glutathione and citric acid [20] and hot-water brushing [21], but no alternative method has been established commercially as yet.

The first objective of our work was to optimize the extraction methods and measurement of the pericarp enzymes implicated in browning (PPO, POD and anthocyanase) and of the anthocyanins. These different components were then measured and compared in two distinct varieties to obtain baseline data for storage trials of different modified-atmosphere and acid-dip treatments as alternatives to $\mathrm{SO}_{2}$ fumigation, that will be reported elsewhere.

\section{Materials and methods}

\subsection{Plant material}

The litchi fruits used were of two varieties: 'Kwai May' came from Reunion Island and 'Wai Chee' from Spain. In these two varieties, the red coloration of the fresh fruit and the structure of the pericarp are very different (figure 1). The fruits were harvested at maturity from orchards of the same age, 
pre-cooled immediately and shipped in cold conditions $\left(12{ }^{\circ} \mathrm{C}\right)$. The sample lots $(20 \mathrm{~kg}$ of each variety) were selected in the orchard for uniformity of size and color, and were free of signs of fungal infection and insect attack. The sample lots were split into four batches of $5 \mathrm{~kg}$. The fruits were immediately peeled and the pericarp flash-frozen upon arrival at the laboratory.

\subsection{Measurement of anthocyanins by HPLC}

\subsubsection{Anthocyanin extraction}

Frozen pericarp ( $2 \mathrm{~g}$ ) (from a mixture of 40 homogenized fruits) was ground with $20 \mathrm{~mL}$ of extraction solution [(2.5\% hydrochloric acid in methanol (v/v))] [6]. After stirring for $20 \mathrm{~min}$, the mixture was filtered through sintered glass (porosity $\mathrm{n}^{\circ} 1$ ). The residue was re-extracted with $20 \mathrm{~mL}$ of the same extraction solution.

The total filtered extract was dried under vacuum at $30{ }^{\circ} \mathrm{C}$ in a rotary vacuum evaporator (RE 100, Bibby Sterilin Ltd., UK), and then solubilized in $2 \mathrm{~mL}$ of methanol. This was then filtered through a hydrophilized PTFE membrane (Filtre Millex $0.45 \mu \mathrm{m}$, Millipore, France) and stored at $-20^{\circ} \mathrm{C}$. The extracts were diluted 20 times in extraction solution prior to HPLC analysis.

\subsubsection{High-pressure liquid chromatography}

The extracts were analyzed with a Spectra System P1000XR chromatograph (Thermo Separation Products, US) equipped with a $20-\mu \mathrm{L}$ injection loop, an automatic gradient controller and a column oven, all controlled by PC1000 software.

Anthocyanins were separated on a Lichrospher 100RP18E column $(5 \mu \mathrm{m}$, $250 \mathrm{~mm} \times 4.6 \mathrm{~mm}$ i.d., Merk Eurolab S.A., France). The column oven temperature was $30{ }^{\circ} \mathrm{C}$. The mobile phase was a mixture of solution A [ $2 \%$ formic acid in water $(\mathrm{v} / \mathrm{v})$ ] and solution B [2\% formic acid in water and $80 \%$ acetonitrile $(\mathrm{v} / \mathrm{v})]$, used with the following gradients [\%A:\%B]: at $0 \mathrm{~min}[97: 3]$, at $4 \mathrm{~min}$ [97:3], at $52 \mathrm{~min} \mathrm{[65:35],} \mathrm{at} 57 \mathrm{~min}$ [20:80], at $61 \mathrm{~min}[20: 80]$ at $62 \mathrm{~min}$ [97:3] and at $70 \mathrm{~min}$ [97:3]. The flow rate was $1 \mathrm{~mL} \cdot \mathrm{min}^{-1}$. The eluted compounds were detected by measuring absorbance at wavelengths between $450 \mathrm{~nm}$ and $600 \mathrm{~nm}$. Quantification was achieved using appropriate standards.

\subsection{Measurement of PPO and POD}

The present protocol was adapted from several published methods. The principal parameters that were optimized were the quantity of polyclar AT, the substrate and the temperature optimum.

Frozen pericarp $(10 \mathrm{~g})$ from 50 fruits was homogenized (Ultra Turrax T 25 Basic, Ika Labortechnik, Germany) with $50 \mathrm{~mL}$ of 0.05-M phosphate buffer ( $\mathrm{pH}$ 6.8) and $3 \mathrm{~g}$ Polyclar AT (insoluble polyvinylpyrrolidone). After centrifugation at $4800 \mathrm{rpm}$ and $4{ }^{\circ} \mathrm{C}$ for 20 min (CR 4.12 Jouan, USA), the supernatant was filtered through a $0.45-\mu \mathrm{m}$ Millipore filter and constituted the enzyme extract.

To measure the activity of PPO, $0.2 \mathrm{~mL}$ of enzyme extract was added to $0.85 \mathrm{~mL}$ of phosphate buffer (pH 6.8) and mixed with $0.6 \mathrm{~mL}$ of $100 \mathrm{mM}$ catechol freshly dissolved in phosphate buffer in a $1.5-\mathrm{mL}$ cuvette. PPO activity was measured at $400 \mathrm{~nm}$ for 3 min $\left(25^{\circ} \mathrm{C}\right)$ with a UVIKON 933 spectrophotometer (Kontron Instruments, Italy) and expressed as $\Delta O D_{400 \mathrm{~nm}} \cdot \mathrm{min}^{-1} \cdot \mathrm{g}^{-1}$ dry matter.

To measure POD activity, $0.1 \mathrm{~mL}$ of enzyme extract was mixed with $0.5 \mathrm{~mL}$ of $10 \mathrm{mM}$ gaïacol solution. The reaction was started immediately by the addition of $1 \mathrm{~mL}$ of $10 \mathrm{mM}$ $\mathrm{H}_{2} \mathrm{O}_{2}$. Activity was measured, at ambient temperature, at $470 \mathrm{~nm}$ for $3 \mathrm{~min}$ as before and expressed as $\Delta O D_{470 \mathrm{~nm}} \cdot \mathrm{min}^{-1} \cdot \mathrm{g}^{-1}$ dry matter.

\subsection{Measurement of anthocyanase activity}

The method used was that of Zhang et al. [22], except for the buffer and the centrifugation speed and duration. Frozen pericarp $(4 \mathrm{~g})$ was homogenized with $10 \mathrm{~mL}$ of sodium acetate buffer ( $\mathrm{pH} 4.0)$ and Polyclar AT (insoluble polyvinylpyrrolidone at $10 \%$ of pericarp weight). The homogenate was 
Figure 2.

Content of the two major anthocyanins in 'Kwai May' and 'Wai Chee' litchis. Vertical bars indicate the standard error and each value is the mean of 10 data points.

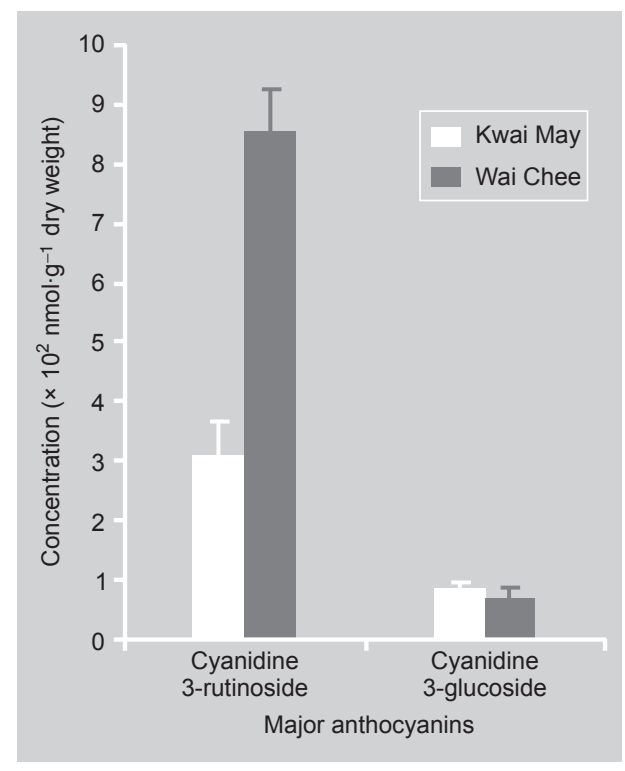

centrifuged at $4800 \mathrm{rpm}$ and $4{ }^{\circ} \mathrm{C}$ for $20 \mathrm{~min}$, the supernatant representing the crude enzyme extract.

One $\mathrm{mL}$ of enzyme extract was added to $4 \mathrm{~mL}$ of $0.05 \mathrm{mM}$ cyanidin-3-glycoside (Extrasynthèse, France) dissolved in sodium acetate buffer ( $\mathrm{pH} 4.0)$. After incubation for $10 \mathrm{~min}$ at $40{ }^{\circ} \mathrm{C}, 5 \mathrm{~mL}$ of $0.1 \mathrm{M} \mathrm{HCl}$ was added to the mixture and the absorbance recorded at $510 \mathrm{~nm}$ for $3 \mathrm{~min}$. Anthocyanase activity was expressed as $\Delta \mathrm{OD}_{510 \mathrm{~nm}} \cdot \mathrm{min}^{-1} \cdot \mathrm{g}^{-1}$ dry matter.

\subsection{Determination of dry matter}

Twenty litchi fruits were peeled and between $2 \mathrm{~g}$ and $5 \mathrm{~g}$ of pericarp were predried at $70{ }^{\circ} \mathrm{C}$ for $24 \mathrm{~h}$ in an ULM 500 oven (Memmert, Germany), then dried under vacuum at the same temperature in a 45003 oven (Bioblock Scientific, US) for between $24 \mathrm{~h}$ and $48 \mathrm{~h}$ until the mass did not vary by more than $1 \mathrm{mg}$. The dry matter content was expressed as a percentage of the fresh weight.

\section{Results and discussion}

It is important to note that the two varieties, though harvested from orchards of the same age, were grown in very different condi- tions: Kwai May in a tropical climate (Reunion Island) and Wai Chee (Spain) in a Mediterranean climate. The coloration and structure of the peel were totally different in the two varieties.

\subsection{Anthocyanin content}

The two litchi cultivars studied had the same HPLC profile and identical major constituents. Nevertheless, Wai Chee was richer in the amount of anthocyanins than Kwai May, in which the concentration of cyanidin-3rutinoside was only $36 \%$ of that in Wai Chee (figure 2).

It was found that cyanidin-3-rutinoside was 12.3 times more abundant than cyanidin-3-glucoside in Wai Chee, but in Kwai May, it was only 3.6 times more abundant. In the cultivar Kwai May, Le Roux et al. [23] found cyanidin-3-rutinoside and cyanidin-3glucoside present in a ratio of 4 to 1 . For the cultivar Wai Chee, Zhang et al. [8] reported that cyanidin-3-rutinoside was the major anthocyanin present in the pericarp, representing $97 \%$ of the total (32.3 times more abundant than all other anthocyanins). Cyanidin-3-rutinoside therefore appears to be particularly abundant in the cultivar Wai Chee, with the maximum proportion of anthocyanins as cyanidin-3-rutinoside $80 \%$ in Kwai May [6] and $75 \%$ in the cultivar Brewster [7].

It should be noted that results could vary according to the methods of extraction and measurement used, and the geographical origin of the material, as well as the age of the tree, the position of the fruit in the tree, the soil type and the climate. For HPLC analysis, Lee and Wicker [5] found a ratio of cyanidin-3-rutinoside to cyanidin-3-glucoside of 6.7 for the cultivar Brewster grown in Florida, while Riviera-Lopez [7] found a ratio of 4.4 for the same cultivar grown in Mexico.

\subsection{PPO, POD and anthocyanase activity}

The activities of PPO, POD and anthocyanase were greater in the cultivar Kwai May than in the cultivar Wai Chee (figures 3, 4). PPO activity was 6 times greater in Kwai 
May than in Wai Chee, and the activity of POD 30 times greater. In both cultivars, it was found that POD activity was greater than that of PPO. These observations tend to confirm those of Zauberman et al. [16] and Zhang et al. [24].

The [POD / PPO] ratios obtained here are lower than those reported in the literature: [14.1 $\Delta \mathrm{OD}_{470 \mathrm{~nm}} \cdot \mathrm{min}^{-1} \cdot \mathrm{g}^{-1}$ dry matter / 30 $\Delta \mathrm{OD}_{400 \mathrm{~nm}} \cdot \mathrm{min}^{-1} \cdot \mathrm{g}^{-1} \mathrm{dm}$ ] for Kwai May [16] and $\left[2.2 \Delta \mathrm{OD}_{470 \mathrm{~nm}} \cdot \mathrm{min}^{-1} \cdot \mathrm{g}^{-1} \mathrm{dm} / 7.2\right.$ $\Delta \mathrm{OD}_{400 \mathrm{~nm}} \cdot \mathrm{min}^{-1} \cdot \mathrm{g}^{-1} \mathrm{dm}$ ] for Wai Chee [24]. This is probably because these different authors used 4-methyl catechol as a substrate for the measurement of PPO, whereas we used catechol, which has a greater affinity for the PPO present in litchi pericarp [12].

The activity of anthocyanase was almost twice as great in the cultivar Kwai May as in Wai Chee (figure 4). The degradation of anthocyanins and its relation to browning in the litchi pericarp is complex. PPO and POD have, in fact, low affinities for anthocyanins, probably due to stearic hindrance caused by sugar moiety [25]. Zhang et al. [22] demonstrated an anthocyanase activity in litchi pericarp and it is thought that this enzyme, also known as anthocyanin- $\beta$-glucosidase, removes the sugar moiety from anthocyanins to form anthocyanidins, which are then oxidized by PPO and POD in the presence of phenolic compounds to form colored products.

Differences in enzyme activities may therefore only partly explain differences in browning, because other factors such as membrane stability and the metabolism of other polyphenols are important factors in anthocyanin degradation. The results presented here will be used in a follow-up to this study, which will test modified atmosphere storage and acid dips to prevent pericarp browning in the two cultivars.

\section{References}

[1] Chapman K., Tropical tree fruits for Australia, Ntl. Libr. Aust. Catalog. Publ. Data, Qld. Dep. Prim. Ind., Brisbane, Australia, 1983, 179 p.

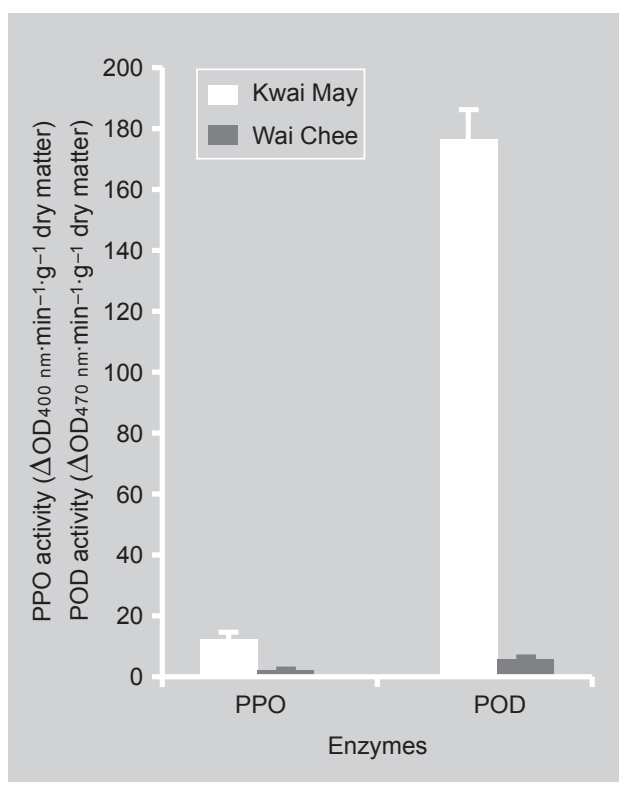

Figure 3.

Polyphenol oxidase (PPO) and peroxidase (POD) activities in 'Kwai May' and 'Wai Chee' litchis. Vertical bars indicate the standard error and each value is the mean of 15 data points.

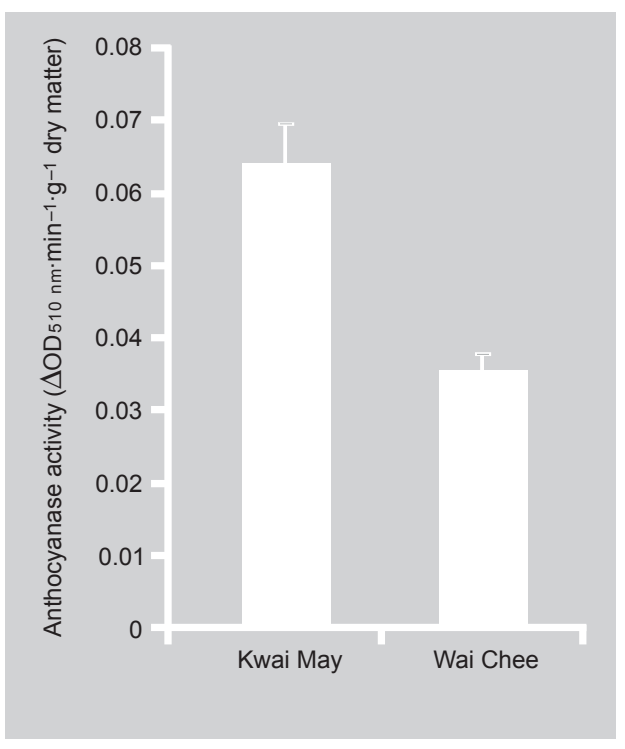

Figure 4.

Anthocyanase activity in 'Kwai May' and 'Wai Chee' litchis. Vertical bars indicate the standard error and each value is the mean of 15 data points.
[2] Nip W.K., Handling and preservation of lychee (Litchi chinensis Sonn.) with emphasis on colour retention, Trop. Sci. 28 (1988) 5-10.

[3] Holcroft D.M., Mitcham E.J., Postharvest physiology and handling of litchi (Litchi chinensis Sonn.), Postharvest Biol. Technol. 9 (1996) 265-281.

[4] Prasad U.S., Jha O.P., Changes in pigmentation patterns during litchi ripening flavonoïd, J. Plant Biochem. 5 (1978) 44-49. 
[5] Lee H.S., Wicker L., Quantitative changes in anthocyanin pigments of lychee fruit during refrigerated storage, Food Chem. 40 (1991) 263-270.

[6] Le Roux E., Étude des composés phénoliques et des systèmes enzymatiques impliqués dans le brunissement du péricarpe de litchi (Litchi chinensis Sonn.), Fac. Sci. St.Jérôme, Thèse Chim. Org., Marseille, France, 1999, 203 p.

[7] Riviera-Lopez J., Ordorica-Falomir C., Wesche-Ebeling P., Changes in anthocyanin concentration in lychee (Litchi chinensis Sonn.) pericarp during maturation, Food Chem. 65 (1999) 195-200.

[8] Zhang Z., Xuequn P., Yang C., JI Z., Jiang Y., Purification and structural analysis of anthocyanins from litchi pericarp, Food Chem. 84 (2004) 601-604.

[9] Perret C., Analyse de tanins inhibiteurs de la stilbène oxydase produite par Botrytis cinerea Pers., Fac. Sci. Univ. Neuchâtel, Thèse n¹591, Neuchâtel, Suisse, 2001.

[10] Akamine E.K., Preventing the darkening of fresh lychees prepared for export, Hawaii Agric. Exp. Stn., Univ. Hawaii, Tech. Programme Rep. 127 (1960) 1-17.

[11] Huang S., Hart H., Lee H.S., Wicker L., Enzymatic and colour changes during post-harvest storage of lychee fruit, J. Food Sci. 55 (1990) 1762-1763.

[12] Jiang Y.M., Role of anthocyanins, polyphenol oxidase and phenols in lychee pericarp browning, J. Sci. Food Agric. 80 (2000) 305310.

[13] Finger R.L., Vieira G., Ledsham L.R., Maturity standard and pericarp browning of litchi fruit, Rev. Brasil. Fisiol. Veg. 9 (1997) 15-18.

[14] Zhang Z., Pang X., Xuewu D., JI Z., Jiang Y., Role of peroxidase in anthocyanin degradation in litchi fruit pericarp, Food Chem. (2005) 90 47-52.

[15] Underhill S.J.R., Coates L.M., Saks Y., Litchi, in: Mitra S. (Ed.), Postharvest physiology and storage of tropical and subtropical fruits, CAB Int., Wallingford, UK, 1997, 191-208.
[16] Zauberman G., Ronen R., Akerman M., Weksler A., Rot I., Fuchs Y., Post-harvest retention of the red colour of litchi pericarp, Sci. Hortic. 47 (1991) 89-97.

[17] Underhill S., Bagshaw J., Prasad A., Zauberman G., Ronen R., Fuchs Y., The control of lychee (Litchi chinensis Sonn.) postharvest skin browning using sulphur dioxide and low $\mathrm{pH}$, Frontier in Tropical Fruit Research, Acta Hortic. 321 (1992) 732.

[18] Paull R.E., Reyes M.E.Q., Reyes M.U., Litchi and rambutan insect disinfection: treatments to minimize induced pericarp browning, Postharvest Biol. Technol. 6 (1995) 139-148.

[19] Jiang Y.-M., Fu J., Effect of postharvest treatment with N6-benzyladenine on quality of litchi (Litchi chinensis Sonn.) fruit, Trop. Sci. 38 (1998) 161.

[20] Jiang Y.-M., Fu J., Inhibition of polyphenol oxidase and the browning control of litchi fruit by glutathione and citric acid, Food Chem. 62 (1998) 49-52.

[21] Lichter A., Dvir O., Rot I., Akerman M., Regev R., Wiesblum A., Fallik E., Zauberman G., Fuchs Y., Hot water brushing an alternative method to $\mathrm{SO}_{2}$ fumigation for color retention of litchi fruits, Postharvest Biol. Technol. 18 (2000) 235-244.

[22] Zhang Z., Xuequn P., Ji Z., Jiang Y., Role of anthocyanin degradation in litchi pericarp browning, Food Chem. 75 (2001) 217-221.

[23] Le Roux E., Sarni-Manchado P., Lozano Y., Cheynier V., Phenolic composition of litchi (Litchi chinensis Sonn.) pericarp and mechanisms of browning, in: Shu-Kun Lin, PomboVillar E., Proc. 2nd Int. Electron. Conf. Synth. Org. Chem. (ECSOC-2), Sept. 1-30, 1998, CD-Rom, MDPI, Basel, Switzerland, 1999.

[24] Zhang D.L., Quantick P.C., Effect of chitosan coating on enzymatic browning and decay during postharvest storage of litchi (Litchi chinensis Sonn.) fruit, Postharvest Biol. Technol. 12 (1997) 195-202.

[25] Jiang Y., Duan X., Joyce D., Zhang Z., Li J., Advances in understanding of enzymatic browning in harvested litchi fruit, Food Chem. 88 (3) (2004) 444-448. 


\section{Antocianina y encimas de degaradación de las antocianinas en el pericarpio de los cultivares de lichi Kwai May y Wai Chee cultivados en la isla de la Reunión y en España.}

Resumen - Introducción. Tras la cosecha, los frutos del lichi (Litchi chinensis Sonn.) pierden rápidamente el color rojo luminoso de su cáscara. Se atribuyó el oscurecimiento del lichi cosechado, en gran parte, a la rápida degradación, en la cáscara, de los colorantes rojos de antociadinina relacionados con la oxidación de los componentes fenólicos mediante la oxidasa de polifenol (PPO) y/o la peroxidasa (POD). Asimismo se identificó una antocianosis sin el pericarpio del lichi. Nuestros estudios pretendieron caracterizar dos variedades específicas de lichi diferenciándose considerablemente en cuanto a su color y a su oscurecimiento. Material y métodos. Se estudiaron los contenidos de antocianidinas, oxidasa (PPO) de polifenol, peroxidasa (POD) y antocianosis del pericarpio de dos cultivares de lichi, Kwai May y Wai Chee, desarrollados respectivamente en la isla de la Reunión y en España. Resultados y discusión. La composición cualitativa de las antocianinas preponderantes (3-rutinosido de cianidol y 3glucósido de cianidol) fue idéntica en ambos cultivares estudiados. Sin embargo cuantitativamente la variedad Kwai May tuvo una concentración de 3-rutinosido de cianidol inferior que la variedad Wai Chee (el $64 \%$ menos). Para ambos cultivares este componente representó más del $90 \%$ de las antocianidinas totales. La actividad de la PPO fue 6 veces mayor para la variedad Kwai May que para Way Chee y la actividad de la POD fue 30 veces mayor. La actividad de la POD fue mayor que la actividad de la PPO para ambas variedades. Estas diferencias ayudan a explicar los diferentes comportamientos de los cultivares durante los estudios tras las cosechas.

Reunión / España / Litchi chinensis / frutas / pericarpio / color / antocianinas / catecol oxidasa / peroxídasas / contenido fenólico 